\title{
K.Margaritou
}

\section{THE RISE OF A NEW EMPIRE? DECODING THE EURASIAN GRAND STRATEGY OF RUSSIA AND ITS STRATEGIC ALIGNMENT WITH CHINA}

\author{
DOI:10.20542/2073-4786-2018-1-23-49
}

\section{Introduction}

The Russian grand strategy for Eurasia is not a topical phenomenon but a historic political choice that was initiated after the dissolution of the Soviet Union. For 25 years, Kremlin's task has been to preserve its influence on the former 'comrades' and to contain the expansion of the Western bloc towards Russian western borders. Meanwhile the new sovereign Russian state had to cope with its serious political and economic weaknesses. Primakov, who was Russia's minister of foreign affairs in 1996-1998 and then became its prime minister from 1998 to 1999, made a great effort to keep the Russian Federation stable. Simultaneously, Primakov laid the foundations for the restoration of Russia's power in Eurasian integration processes and for a strategic cooperation with the People's Republic of China. In 2000, Putin, as the new leader of Russia, adopted Primakov's strategy and deployed it on a new threshold that would allow the former superpower to strive for its geopolitical recovery.

The Eurasian Union (EAU) is not to be the 'incarnation of the Soviet Union' (Putin, 2011) but it is an organization that promotes economic integration and development of former Soviet states in the framework of a new institutional mechanism that resembles the patterns of the European integration and corresponds to the conditions of global economic and political governance. Modern Russia resembles the 'soft power' (Nye, 2004) expansion of the EU and adopts a significant grand strategy which responds to that of the US by a 'mixed concept of soft and hard power', in order to become once again an intraregional power that will be preponderant in Eurasia.

The evidence of this strategy can be found in the National Security Strategy of Russia that was re-adjusted four times from 2000 to 2016. According to respective official documents (Security Council 2000; 2008; 2009; 2010; 2013; 2014; 2015; 2016), Russia intends to struggle for a 'multipolar world' and for an upgraded international status similar to that in its imperial past and equal to the 
US. The Eurasian integration and strategic alignment with China become functional means to serve this aim.

Russo-Chinese relations are being developed in the framework of a special strategic partnership to promote the national aims of both sides being not contradictory to each other. Besides their gradual interdependence in the energy, trade and security sectors Russia and China mutually support each other's core and major interests thanks to the alignment of the Eurasian Economic Union (EAEU) and the Collective Security Treaty Organization (CSTO) with the Shanghai Cooperation Organization (SCO) and the One Belt, One Road initiative (OBOR). The Russo-Chinese strategic partnership may be a joint venture that will shift the balance of power at the international level. Key theories of international relations can explain further perspectives of this alliance. Interpreting the Eurasian grand strategy of Moscow in the framework of the analysis provided by the school of realism and combined with Mackinder's (1904) 'Heartland Theory' yield a new dimension of Kremlin's strategic perspectives.

The article is divided into three paras. In the first one the road towards the EAU is highlighted and its formation is examined in the context of Russia's grand strategy, taking into account Russian National Security Strategy and its Foreign Policy concepts. In the second para the importance of the Russo-Chinese strategic partnership related to Russia's grand strategy is analyzed. In the third para incentives for this strategy and its impact on the international system are analyzed in accordance with most influential theories of realism and Mackinder's (1904) geographical considerations on the "'pivot state" in order to evaluate the probable rise of a post-new world order.

\section{The road to the EAEU: its story and Russia's grand strategy}

The EAEU has been a major result of a series of multiple and continuous efforts of Moscow to reverse disintegration that followed the dissolution of the USSR (Margaritou, 2015). Russia actively worked to sustain its influence over the post-Soviet space and to secure unity between the new republics (Meshceryakov, 2014a). The main post-Soviet organization, the Commonwealth of Independent States (CIS), and its military constituency, the Collective Security Treaty (CST), established in 1991 and in 1992 respectively, were functional means for the promotion of a new Eurasian endeavor (Margaritou, 2017). Moscow along with its loyal allies (Astana and Minsk) supported Eurasian integration processes inspired by the N. Nazarbayev, President of Kazakhstan, who publicly proposed estab- 
lishment of the Eurasian Union at the meeting in the Lomonosov University during his visit to Moscow in 1994 (Margaritou, 2015).

In 1995 Russia, Kazakhstan and Belarus established the Customs Union, to which Kyrgyzstan acceded a year later and, in 1999 they additionally formed the Common Economic Space to which Tajikistan also acceded. In 1996 Russia and Belarus founded the Union State of Russia and Belarus (Margaritou, 2017). The same year Russia, Kazakhstan, Kyrgyzstan, Tajikistan and China initialized the 'Shanghai Five' interstate cooperation and, in 2001, followed up by Uzbekistan's joining in, they established the SCO (Margaritou, 2015). In 2000, Russia, Kazakhstan, Belarus, Kyrgyzstan and Tajikistan founded the Eurasian Economic Community (EurAsEC), the ancestor entity of the EAEU, and two years later, they upgraded the CST to the CSTO, to which Armenia also acceded (Ibid).

In parallel, from 1991 to 2001, Kazakhstan, Uzbekistan, Kyrgyzstan, Tajikistan and Turkmenistan undertook multiple efforts to establish a central Asian organization for integration. It was initialized as a Central Asian Commonwealth (1991) (Tolipov, 2005), renamed as a Central Asian Union (1994) accompanied by Tajikistan's and Turkmenistan's withdrawals and as a Central Asian Economic Community (CAEC) when Tajikistan returned back (1998) (Meshceryakov, 2014b). Finally, the CAEC evolved into the Central Asian Cooperation Organization in 2001 and was absorbed by the EurAsEC in 2005, after an accession of Russia (Qoraboyev, 2010). Under the Russian leadership, the EurAsEC became a significant organization for an economic integration of Russia and its allies (Margaritou 2015) It was succeeded by the EAEU that was launched on January 1, 2015 (EEC, 2015a).

Russia, Kazakhstan and Belarus were the founding members of the Union and Armenia and Kyrgyzstan became additional full members of the Union on January 2, 2015 (EEC, 2015b) and on August 2, 2015 (Ibid., 2015c), respectively. Russia is the preponderant power of the Union, being the largest country in the world and the most powerful state in Central and Eastern Eurasia from every aspect. It holds largest proven natural gas reserves in the world and is a leading producer of crude oil, natural gas and refined petroleum products (CIA, 2017). It has a significant transport network and a very developed industrial complex (Russia at a glance, 2018) It also posesses great military capabilities (Blank, 2015) that are deployed across the giant Eurasian landmass. Consequently, Russia 'asserts the right' to lead in Eurasia and in integration processes.

According to E. Vinokurov (2013), the EAEU is considered a 'pragmatic" venture of economic integration motivated by the need 'to modernize'" the economies of member states and 'to resolve pressing problems". Additionally, 
he (Vinokurov, 2017) regards that: 'In addition to geopolitical objectives, (...) the EAEU was established to help its member states make the most of intraregional economic ties (...) and to forge an environment conducive to improving their global competitiveness"'. Indeed, the TEAEU (2014, article 1) stipulates that 'the EAEU is an international organization of regional economic integration"' that aims at 'sustainable economic development, comprehensive modernization and improving competitiveness of national economies within the framework of the global economy' (Ibid., preamble). Moreover, C. Hartwell (2016) regards that despite 'fiscal weaknesses" the EAEU is an entity that has specific 'opportunities" and 'competitive advantages"' in order to 'becoming the world's hub'. In terms of geopolitical objectives, the EAEU is perceived as ''a response to neoliberal globalization'” (Lane, 2015) related to Russia's intention to contain the EU and the US in the contemporary global order. The geopolitical perspectives of the EAEU unfold within 'regionalism"' and processes of "'regional integration"' (Roberts and Moshes, 2016). To this extent, the EAEU comprises two dimensions, an economic and a geopolitical one.

Regarding an economic dimension, the EAEU is a fully functional economic entity that combines ideal means for growth and integration corresponding to the structure of the international economic system. According to various theories (Balassa, 1961; Lipsey, 1960; Lloyd, 1996; Krueger, 1997) customs union and free trade agreements are considered as the optional but interlinked modes for economic development and integration; although deployed in 'stages', (Riezman, 2013) that favour a 'multisectoral integration' both at a regional (Keating and Loughlin, 2004) and at an international (Lang and Ohr, 1995) scale. In essence, the outputs of economic integration processes can be inspected in the global economy that has been built up on the basis of regional economic integration procedures and developed by respective organizations (Gilpin, 2002). The EAEU fully corresponds to the above theories because it brings together a free trade regime, a customs union, an internal market and a single economic space (TEAEU, 2014). More specifically, EAEU integration has already completed four decisive 'stages" of integration since the beginning of its existence in contrast with other organizations and entities such as NAFTA, ASEAN and the EU. Although the latter is the most successful economic and political project in global integration history, it has been formed through many stages of integration and has dealt with centrifugal forces over decades (Glencross, 2014).

Furthermore, the EAEU is fully functional because it operates the Customs Union (CU) and the Common Economic Space (CES) with an array of policies that support further integration in many areas. S. Apostolakis and K. Margaritou 
(2018) underline that 'the CU favors entrepreneurship and economic development of the Union"' by the provisions on 'the internal market, the free economic areas and warehouses the Common Customs Tariff and the foreign trade policy of the EAEU taking into consideration the WTO law'. The CES regulates a broad spectrum of policies that contribute to a sustainable economic development. Apostolakis and Margaritou (2018) mark also that 'implementation of policies on liberalization of trade in services and incorporation activities, competition, industry, agricultural and intellectual property are deliberately supported by macroeconomic, monetary and tax policies as well as by the policies on services and infrastructure at the sectors of energy and transport and the regulations on migration ensuring the convergence, cohesion and integrity of member states on the overall function of the Union".

In this regard, functionality of the EAEU corresponds to respective theories on integration. Organizations and entities that urge integration in 'functionalism' mode (Mitrany, 1944) and implement the 'spill over method' (Nye, 1968), attain to extend their authority (Haas, 2008) in multiple sectors (Rosamond, 2000), such as trade, energy, economy, markets and security, leading eventually at the supranational state model. EAEU policy-making and implementation of EAEU law (Apostolakis and Margaritou, 2018) illustrate the probability for the Union to be evolved to a supranational organization confirming V. Putin's vision (2011).

Organizations and entities such as the EAEU correspond to the theory of Grand Strategy. Prominent Grand Strategy theorists, such as Papasotiriou (2011), Hart (1991) and Luttwak (1987) contend that great powers promote international cooperation and multilateral organizations to ensure their interests without military conflicts. They try to exploit their resources and to attract allies and partnerships in the fields of economy, policy and security to maximize their influence and power based on permanent and mutually beneficial ties with other states. Integrative organizations provide either an intergovernmental or a supranational law order additionally to a proportional hierarchy that empowers the preponderant unit of the organization with several responsibilities on the economic and political fields. The most important aspect of these organizations is that the preponderant power transmutes hierarchical system into an advantageous institutional assembly that favors its future predominant status over other members (Bull, 2002).

In the case of the EAEU, Russia, the preponderant power of the Union, transmutes hierarchical system into a collegial assembly that favors national interests of member states. Despite the fact that it 'accounts for more than $80 \%$ of the 
Union's GDP' (Kirkham, 2016) and receives revenues from the imports to the Union at a very high percentage $(87.97 \%)^{1}$ (TEAEU 2014, protocol 5, article 12), it proportionally contributes to the EAEU budget (ARKA, 2015) and disposes significant state resources, structures and capabilities for the establishment of 'common markets of gas, oil and petroleum products and electricity' (TEAEU, 2014, articles 81, 83-84) as well as to the creation of a 'common transport area', unifying networks and transport on land, air and water (Ibid, articles 86-87).

Furthermore, Russia shares its political power within the framework of EAEU institutions and policy-making. All member states are equally represented by Heads of State (Supreme Eurasian Economic Council-SEEC), Heads of Government (Eurasian Intergovernmental Council-EIC), Deputy Heads of Government (Council of the Eurasian Economic Commission-EEC), Commissioners (Board of the EEC, two nationals from every member state) and Judges of the Court (Court of the Union, two national judges from every member state) (Ibid., articles 10,14, annex 1 and annex 2). Policy-making and decision-making procedures are conducted equally and by consensus. All state representatives have a single vote and "'decide mostly by consensus" (SEEC, EIC and EEC) otherwise with qualified majority (Board of the EEC) (Apostolakis and Margaritou, 2018; TEAEU, 2014, articles 13, 17 and 18). The national interests of member states are fully 'reflected and incorporated in integration process', (Apostolakis and Margaritou, 2018). Therefore, Russia's preponderance in the EAEU is a sample of a 'soft power emergence' and of a 'good hegemony'.

The EAEU integration comprises security and military aspects, as soon as its member states (plus Tajikistan) are military allies in the CSTO that is an ideal supplementary organization for the security integration of the prospective EAU. In case of aggression against any member state, the "'mutual defense clause commits member states with collective armed response”' (CSTO, 2002; RT, 2012) and boosts the potential of the Russian hard power. Russia stations military forces and operates military bases on the territories of its allies:

'A) In Belarus, which is unified with Russia in the military sector, in the framework of the Union State, Russian Aerospace Defense Forces handle the 'Volga type' surveillance radar in Hantsavichy for the protection of the Northwestern Russia.

\footnotetext{
${ }^{1}$ The distribution of import revenues for Russia has changed to 85,32\% since the accession of the new members. Contribution rate to EAEU budget can be modified by a decision of the Supreme Eurasian Economic Council (TEAEU, 2014, article 20).
} 
B) In Kazakhstan, the Baikonur cosmodrome.

C) In Armenia, in the Gyumri Region, the $102^{\text {nd }}$ military base which ensures the protection of Nagorno-Karabakh.

D) In Kyrgyzstan, the air force base in Kant.

E) In Tajikistan, the $201^{\text {st }}$ missile base’' (Margaritou, 2015).

In the sphere of geopolitics, the EAEU can be interpreted as Moscow's counterstrategy to contain a contagious expansion of the EU and NATO in Eurasia (Margaritou, 2017). Russia faces a dual threat: enlargement of the EU by incorporating Russia's partners in the CIS or an economic and political penetration in Eastern Europe and Central Asia as well as the expansion of NATO towards Russian borders (Ibid.). To N. Lomagin (2014) and L. Arakelyan (2014), Russia conducts its foreign policy in Eurasia to increase its power in its former spheres of influence.The CIS and the EAEU are instruments to accomplish this strategy. G. Persson (2013) considers that Russia has become more assertive since Putin's return to presidency (2012); his vision has been to build up a Russia that will be preponderant in Europe and Asia in order to replace the EU in the Western Hemisphere as an alternative pole of power because of serious weaknesses of the latter in military and policy fields (Ibid.) ''to end US hegemony' (Shearman, 2015).

Be that as it may, the EAEU should be considered as the central pillar on the deployment of Kremlin's contemporary grand strategy, because it fully corresponds to provisions of Grand Strategy theory and interacts with potential risks in the sphere of geopolitics reflecting a great 'strategic depth' of the terminal aims of Eurasian integration (Margaritou, 2015). Pursuant to these conditions, Russia assures political integration of the EAEU, because it obtains economic and military control over the large transcontinental landmass of Eurasia regaining influence and mostly geopolitical power across a significant region to revive its former preponderance. This strategy is defined in Russia's concepts of National Security Strategy and Foreign Policy in addition to Military Doctrines from 2009 onwards.

Margaritou (2018) contends that since the breakup of the Soviet Union thus far, Russia has had to re-adjust its national security strategy and its foreign policy priorities four times.

The first period can be related to 1991-2004. At its initial stage under Yeltsin's administrations (1991-2000) the Kremlin was trying to stabilize the Russian state and silently accepted US preponderance in the Western Hemisphere accompanied by deterioration of Russia's influence in Eastern Europe. Nevertheless, during 1996-1999, Y. Primakov tacitly managed to lay foundations of the Eurasian integration underpinning Putin's trestle for the future 'pivot in Eurasia'. 
In the years that followed (2000-2004), Putin fostered friendly relations with the US and a personal trustworthy communication with G. Bush that conduced to the common US-Russian military exercises under NATO's shield in the Russian Kaliningrad oblast to fight global terrorism. Unfortunately, this common sense began to fall apart due to the US invasion in Iraq, in 2003. Gradually, between 2000 and 2009, the National Security Strategy of Russia radically changed (Ibid.).

After the second period (2004-2008), when Russia in the aftermath of the Russo-Georgian war re-adjusted its policy once again in Eurasia, the Foreign Policy concept (2008) and the National Security Strategy up to 2020 (Security Council, 2008; 2009) introduced an advanced status for Russia in the international system. The former superpower, which struggled for a 'multipolar world' (Security Council, 2000), aimed once again in its National Security Strategy 2009-2020 (Security Council, 2009) to become equal to the US in order to prevent 'Washington's dominion in a unipolar system". The means to achieve results in this venture were identified by the then Prime Minister Putin in the context of the Eurasian integration. In 2011, Putin publicly notified his personal strategy on the EAEU and the CSTO considering them as the "forerunners" for the future supranational EAU (Putin, 2011). Above and beyond, he pleaded for a future 'EUEAU harmonization', in a special zone across Eurasia, 'from Lisbon to Vladivostok', (Ibid.).

The third period (2009-2015) was accompanied by two Military Concepts (Security Council, 2010; 2014), a new National Security Strategy (Security Council, 2015) and a new Foreign Policy Concept (Security Council, 2013). In all of these official documents the Eurasian integration was named a main strategic priority besides the right for Russian armed forces to 'repel aggression against Russia's allies'. In the National Security Strategy (2015), the Security Council of the Russian Federation blamed Western powers for the 'Ukrainian Maidan revolution' and general instability in the world. Crimea and Syria became symbols of a new strategic time, the fourth period in Russia's modern grand strategy that was initiated between 2015-2016 (Security Council, 2016) to combine economic integration of Eurasia with the Russian political and hard power (Margaritou, 2018).

The Eurasian grand strategy of Russia can be identified and assessed by specific theoretical tools. Papasotiriou (2011) has deliberately yielded an analysis of Grand Strategy with regard to an array of 'macroscopic types' . Most relevantly, Papasotiriou (Ibid.) considers that Grand Strategy’s identification is thoroughly promoted by ' 'the Strategy of Containment - Expansion, the Strategy of Alliances, the Counterbalance Strategy and the Strategy of Appeasement'’. These strategies 
are the "'ideal types" that can interpret a state's foreign policy, diplomacy and international relations validating also their effectiveness to specific criteria, namely 'the appropriateness, internal cohesion, effectiveness, interlinkage between capabilities and objectives as well as durability failure'” (Ibid.).

Adjusting the Eurasian grand strategy to the 'macroscopic types', it can be drawn that the EAEU brings together the "'Strategy of ContainmentExpansion', the 'Strategy of Alliances' and the 'Counterbalance Strategy'. On the one hand, the EAEU (EAU) is a strategy for containment of the EU and NATO. On the other, it is an integration process that institutionalizes and increases Russia's potential geoeconomic control and geopolitical influence in its former spheres of influence. Secondly, it is a strategy that favors alliances between Russia and former Soviet states as well as with other states of Eurasia such as China thanks to the fact that Russia is a great political and military power and promotes a 'soft power' leadership and a 'good hegemony' in the mode of intraregional integration. Thirdly, it counterbalances the EU, NATO and the US presence in Eurasia.

With respect to effectiveness, the Eurasian grand strategy brings together three criteria of evaluation: 'Appropriateness', ' 'internal cohesion', and ''interlinkage between capabilities and objectives"' (Margaritou, 2015). The EAEU (EAU) is deployed in connection with international developments and globalization that consist of various regional integration processes (Katzenstein, 1996). It is an integration project that adopts patterns of global governance to attract partners and promote alliances to expanding Russian potential within the framework of international organization and not outside of it (Margaritou, 2015; Apostolakis and Margaritou, 2018). Additionally, it is possessed by internal cohesion thanks to the fact that Eurasian member states have been former integral parts of the Soviet Union and are based on common bonds such as tradition, culture and language (Hartwell, 2016). The main objectives of the EAEU is the economic integration which is effectively promoted thanks to EAEU governance (Apostolakis and Margaritou, 2018) and the disposal of Russian economic and security capabilities in favor of member states paving the way for a successful deepening of integration. Finally, it must be marked that the EAEU has no record of failure.

In a nutshell, the EAEU and its potential integration and deepening to the EAU, taking into consideration the CSTO, represents a strategy that is totally effective. Russia has ensured its influence on the former Soviet states and shall be able to assert preponderance in Eurasia to challenge the US at the international level. However, this challenge cannot be unilateral since US preponderance was established in a multilateral framework of collaboration with European powers. 
Respectively, Russia needs a powerful ally that shall align with the Eurasian grand strategy and gives an insight of no conflict of strategic interests in the long run. This ally seems to be China.

\section{The Eurasian Russo-Chinese strategic partnership}

Russo-Chinese strategic partnership derives from the fact that 'the two sides have no conflict of major strategic interests in terms of grand strategy as well as from their gradual interdependence at the sectors of energy, trade and security' (Margaritou, 2017). To a greater extent, S. Aris (2009) considers that Russo-Chinese strategic partnership in the framework of SCO can be "an antiWestern bloc'" beyond the sphere of regional cooperation.

To Margaritou (2017), the Chinese grand strategy has been formulated in the context of 'peaceful development' according to the 'White Papers"' of the State Council of the PRC (2011a; 2011b). With respect to the "'White Paper on Peaceful Development', China aims to social and economic development in the long run (State Council, 2011a). The Chinese president, Xi Jinping, has communicated his 'Chinese dream"' considering that modern China must ensure 'human and economic development"' (China daily, 2014). To this objective, the State Council (2011b) has declared that 'national defense policy' of China depends on the so-called ''Five Principles of mutual respect for sovereignty and territorial integrity, mutual non-aggression, non- interference in each other's internal affairs, equality and mutual benefit and peaceful coexistence'” (China.org, 2014) that constitute 'the major pillar of China's foreign policy' (Panda, 2014).

In the long run, main strategic objective of China is to assert global economic leadership (Papasotiriou, 2013; Mearsheimer, 2013, 77-93) deploying projects such as the OBOR that will favour its permanent economic preponderance in Europe and Asia (Margaritou, 2017). Consequently, according to the 'macroscopic types", the Chinese grand strategy corresponds to the 'Strategy of Containment-Expansion', the 'Strategy of Alliances' and the 'Counterbalance Strategy'. Bidding for economic preponderance in Eurasia and at a global scale, China has to contain EU penetration in Asia and US expansion in Southeast Asia and the Middle East, while has to expand its geoeconomic control over the respective areas. In this venture, it needs a powerful political and military ally that seems to be Russia. Moreover, an alliance with Russia can counterbalance geoeconomic and geopolitical control of the Western powers over Eurasia and at a global scale. Therefore, the three 'macroscopic types"' adjusted to Russia and China are intersected at the levels of alliances, containment-expansion and counterbalance 
but they have different aims both in Eurasia and at a global scale, the strategic objectives being political preponderance of Russia and economic preponderance of China.

Russia and China shall be considered as the 'cordial allies' of Eurasia, increasing their interdependence in the energy, trade and security sectors as well as in the sphere of international relations (Margaritou, 2017). China has a great need of energy supplies and Russia can be its most valuable partner taking into consideration projects such as the 'Power of Siberia' corridor and the 30-year agreement for the Russian gas deliveries to China (Gazprom, 2017) as well as problematic relations of China with other states (e.g. Japan and South Korea) in the South and East China Seas (Papasotiriou, 2013; Margaritou, 2017). In the trade sector, the volume of mutual trade shows an increasing trend and the two sides aim to expand significantly their trade turnover (RT, 2018) and mutual investments as well as to conduct mutual payments in national currencies in order to 'decrease dependency on external factors" (RT, 2016a). In the security sector, the two great powers of Eurasia collaborate in military technology and join their forces in the SCO in the framework of RATS (Regional Antiterrorist Structure) that operates as a center to combating terrorism at a cross-border scale via the Northwestern Chinese autonomous region of Xinjiang, Kazakhstan, Russian Caucasus, Kyrgyzstan, Tajikistan and Uzbekistan. In the framework of RATS, the SCO and the CSTO have signed an agreement to enhance their cooperation on trans-border security issues and their members periodically hold joint military exercises paving the way for a deeper collaboration in the future (Boland, 2010; Tiezzi, 2014).

In the sphere of international relations, Putin has stressed that both Russia and China extend their partnership in this field because their "'views are either very similar or coincide'” (RT, 2016b). Putin has underlined that Russo-Chinese relations are dually being strengthened both bilaterally and multilaterally into the framework of a 'closer cooperation in Eurasia', (The President of Russia, 2016a). Putin estimates that China-EAEU partnership can be promoted in SCO integration. Consequently, the SCO is becoming the ideal supplementary organization for a further expansion of the Russo-Chinese strategic partnership in the nexus of intraregional integration. Respectively, the President of China, Xi Jinping, has acknowledged that Russo-Chinese strategic partnership may be the bond for an ' 'eternal friendship', between the two peoples (The President of Russia, 2016b) and the SCO as an ideal framework for integration between the OBOR and the EAEU. Putin has argued that the EAEU can be linked with the OBOR with the attendance of the SCO and the CIS in favor of the stability in Eurasia and has marked also the perspectives on the enhancement of SCO security mechanisms 
after the accessions of India and Pakistan to the Organization (Ibid.); additionally, he has pleaded for an Iran's membership in the future (Reuters, 2016).

It is obvious that common intention of the two powers is the establishment of a new geoeconomic order in Eurasia within the framework of a multi-faceted geopolitical structure that shall redistribute the balance of power at the international level. The SCO is of great importance for the accomplishment of Eurasian integration processes embodying the Russo-Chinese relations in a 'win-win' institutionalized platform and securing the integrity of Eurasian integration participants to establish a new economic and political pole in favour of EAU interests (Margaritou, 2017). The EEC seeks EAEU's association with other Eurasian powers such as India, Iran, Israel and Egypt (EEC, 2017) as well as collaborations with the APEC and ASEAN countries (EEC, 2016). At the same time, the Russian-Chinese led SCO promotes the OBOR in the relevant areas and empowers Russia and China to pursue new alliances and bargains with other great powers in international organizations and fora such as the UN Security Council, WTO, G 20 and the APEC.

Taking into consideration the geography of Eurasia, it can be drawn that Russian grand strategy is being supported by the Chinese one at the level of Eurasia and vice versa at the level of the international system. The Russo-Chinese strategic intersection is multisectorially deployed to serve a dual goal; the political preponderance of Russia in Europe and Asia attended by the economic supremacy of China. Probably, Putin's Russia has already become the preponderant political and military power of Eurasia, given the victory in Russo-Georgian war, the annexation of Crimea by a referendum and the historic intervention in Syria. The EAU foreshadows Russia's geopolitical expansion and gradually consolidates the advanced status of a global superpower that will be equal to this of the US. China follows Eurasian grand strategy to promote its own strategic interests. The EAEU and the SCO become ideal institutional fields on which the two great powers of Eurasia stabilize their dominion over the relevant area.

\section{Key-theories decoding the Eurasian concept of the modern grand strategy of Russia}

In its classical tenet Realism considers ' 'politics as a struggle for power and unilateral advantage” (Lebow, 2013, 59-76). H. Morgenthau (1947) argued that "foreign policies of great powers have survived all changes" and there is 'continuity' in the last two centuries, due to national objectives that are dictated by 'geography, national character, tradition and the actual distribution of power 
(...) factors which a government can neglect only at the risk of failure', (Ibid., 6162). Hence, the 'status quo' position in a state system is dictated by the protection and the expansion of its interests (Ibid., 1978).

Adjusting Classical Realism's interpretation to modern Russia it can be concluded that Moscow develops Eurasian integration in accordance with $\mathrm{Y}$. Primakov's legacy. The Eurasian grand strategy preserves continuity in Russian foreign policy that has been embedded thanks to Primakov's initiatives (Margaritou, 2018). As the spiritual successor of Primakov, Putin has become an architect of Russia's grand strategy and continues the strategic tradition of his predecessor expanding the post-Soviet institutional base to a new ideological and political direction (Ibid.); Eurasian integration strategy seems to correspond to the spectrum of modalities of the 'new world order'.

Both Defensive and Offensive Structural Realism unravel the impact of the Eurasian grand strategy at the level of the international system. The great Defensive Realist, K. Waltz (1979, 60-101), considered the international system as an ' 'anarchic' one, in the absence of a "'high authority"; although organized on 'indiscernible structures" that sway the system by the exportation of superpowers' internal processes to the great powers and other states which, in turn, internalize, adapt and re-export them customized, bidding for the status of a superpower or a great power, respectively. The exportation and importation of these procedures form an interdependent whole based on functional inputs and outputs formulating the national strategies. The prevailing national grand strategy is being distinguished as the "ordering principle" of the whole disclosing the 'ordering superpower' of the system (Ibid.). 
Figure 1: The International System according to Waltz

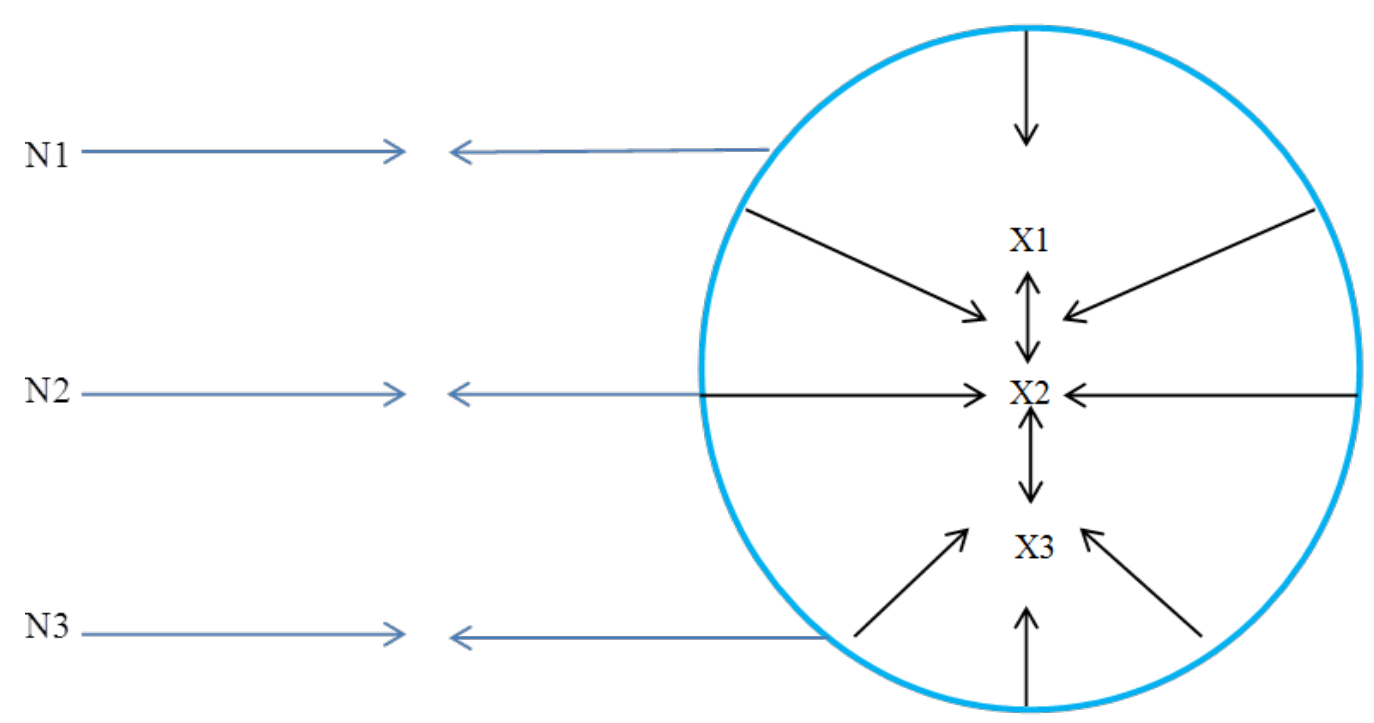

Source: K. Waltz (1979)

To Margaritou (2017), figure 1 (Waltz, 1979) shows the international system according to the 'Waltzian theory'. Where N1, N2, N3: the 'ordering principles', i.e. the 'ordering superpowers', that define the functions, the structures, and the patterns of the system. X1, X2, X3,...Xi, are the units intended to improve their status position inside the system and accept the terms of participation in international organization as well as the limits of action inside it. The 'balance of power' is redistributed and the system is transformed when an 'ordering principle replaces another according to its various capabilities and their general distribution among the participating powers"' (Ibid., 100-101).

To Waltz (Ibid., 187), there is a permanent 'security dilemma', in international politics, because of "the similar functions of the states that duplicate one another's activities" in order to prevail. In general, the survival of a state in the ' 'anarchic world order"' is ensured by 'the self-help principle', (Ibid.), namely the coordinated relations among states and their political, economic and military transactions embedded by patterns and conditions from the side of those who are preponderant. The "security dilemma"' of the Russian Federation can be detected in the sphere of geopolitics. The Kremlin has adopted 'ordering principles" of the system and patterns of a transatlantic economic and security integration as 
well as the 'spill-over" processes of the EU to deal with expansion of the US-led Western coalition towards Eastern Europe and Southwestern Asia (Margaritou, 2017).

According to Waltz (2000), after the dissolution of the USSR, the system of international relations comprises US strategic objectives. The foundation of the Western European Union and its interconnection with NATO, including the expansion of the latter into Eastern Europe, and combined with the EU enlargement by incorporating former Soviet and communist republics (1999-2003), come in alignment with national security priorities of the US. In the two decades that followed the end of the Cold War, the NATO - EU alignment has become a significant political pillar in the Western Hemisphere for international community institutions to empower the US global preponderance. In the economic field, implementation of liberalization processes and interaction between respective institutions such as the UN development program, WTO, G8 and G20 fora, Eurozone and NATO's growing influence in North Africa and Southeastern Mediterranean Sea has consolidated a 'new world order' in which the USA has been the preponderant power followed by the EU.

Simultaneously, American preponderance has been embedded due to the US hard power supremacy. H. Bull (2002, p. 208) has argued that the US has attained the status of a predominant hard power ''enjoying always the leadership in NATO'. After the 'Desert Storm' in Iraq (1991) the settlement of Yugoslavia dissolution, the wars against terrorism in Afghanistan and Iraq and efforts for democratization of Iraq and other Arab countries in the aftermath of the 'Arab Spring', Washington has confirmed Nye's (2008) argument on ''US military supremacy" over a system that is being considered gradually as a 'multipolar one in the economic field"'. The American grand strategy synthesizes 'a blend of soft and hard power' dynamics establishing an international system that is politically and security driven by the US followed by EU powers and established on the fundamental liberal principles of contemporary international relations.

Eurasian integration and the Russo-Chinese strategic alignment come at the forefront of the Kremlin's 'self-help principle"' effort to cope with Western powers' political preponderance in international politics. Notwithstanding, this response is not only a systemic reaction as it is provided for by Defensive Realism but, according to Classical Realism, 'it is a struggle for power and unilateral advantage"' (Lebow, 2013, 59-76) and a re-orientation of the Russian grand strategy to the accomplishment of historic national objectives (Morgenthau, 1947).

Offensive Realism provides the ground for a deeper analysis. The most prominent of the Offensive Realists, J. Mearsheimer (2001), considers the world 
as a single system divided in areas such as: 'Europe, Northeastern Asia and the Western Hemisphere'”. Political and economic control over these areas can be perceived as the key for global preponderance; a state power that attains control shall be the "'regional hegemon' (Ibid.). To Mearsheimer, the "'planet hegemon"' does not exist; the US is the most powerful state unit of the system and the 'regional hegemon in the Western Hemisphere'”. It cannot be a 'planet hegemon'” because of 'the presence of oceans on much of the earth's surface'. The perfect outcome for a great power is to become a 'regional hegemon"' and to control probably another accessible land region (Ibid.).

In the case of the Russian led EAU, respective control over large parts of Eastern Europe, Central and Eastern Asia will pave the way for the rise of Russia in the body of the EAU at the N2 position of the 'ordering power' of the international system redistributing the total balance of power. To this extent, the Russian grand strategy promotes this perspective to gain a multifarious advantage in alignment with China. The strategic perspective of this alignment is dualistic: The political and military preponderance of Russia and the economic preponderance of China both in Europe and Asia and at a global scale.

In Figure 2 (Margaritou, 2017), contemporary dynamics of international politics are being deduced. The system is 'multipolar', still under America's 'ordering principles"' and its great military and economic capabilities but the functional interaction between the principles seems to favor the two great powers of Eurasia. Russia and China are in an alliance which is based on integrative institutions and organizational structures such as the SCO, EAEU and OBOR that encompass their mutual beneficiary collaboration. This is an alternative dimension of the USA-NATO-EU alignment that indicates the post-Cold War distribution of capabilities and the total balance of power. The USA has been a superpower increasing its security-driven political preponderance in the Western Hemisphere followed by the EU that has been a great power promoting its interests mostly in the economic sector thanks to US military and political capabilities. Respectively, the Russo-Chinese alignment can be considered as a 'common self-help principle' that imitates the successful alliance between the US and the EU both at the levels of their political, military and economic interdependence as well as at the level of their strategic objectives (Ibid.). 
Figure 2: The contemporary International System according to the Waltzian one

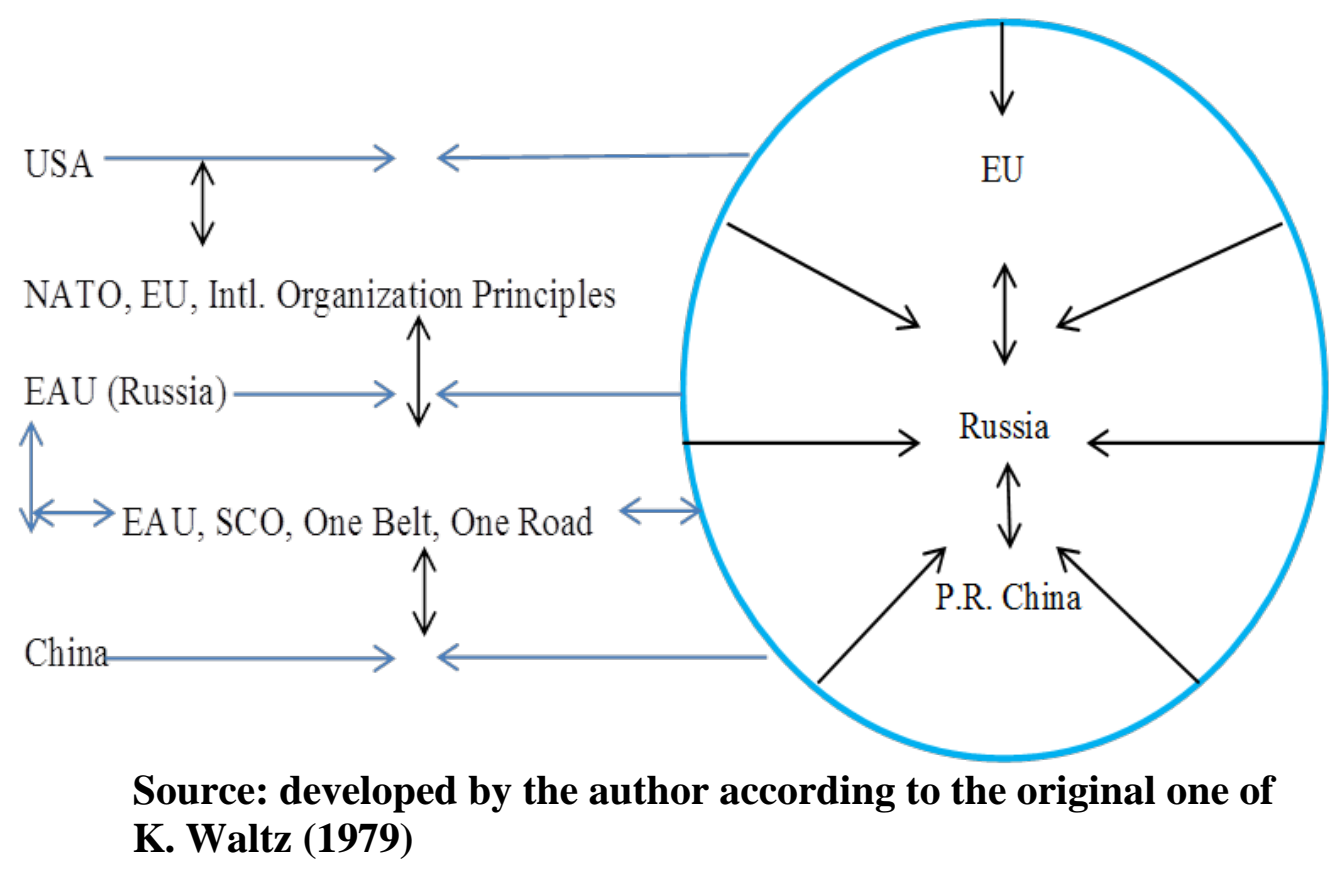

As a great political and military power Russia pursues a preponderant political and military status in Europe and Asia in order to become an ordering superpower at the level of the international system challenging US supremacy (N1). In tandem, China (N3) has similar incentives with these of the EU at a global scale. Consequently, there is an imperative strategic interdependence between Russia and China that support each other regarding their capabilities. In brief, there is a common Russo-Chinese endeavor that may emerge as a new political and military 'ordering power' and a new economic 'ordering power' which are motivated by the 'ordering principles', (Waltz, 1979) that have been generated by the American supremacy during the post-Cold War era.

Why does Russia invest in the Eurasian grand strategy and chooses China as a 'cordial ally' instead of an approach with EU powers or a direct linkage with the US and NATO? Mackinder's theory completes the decoding of the Eurasian grand strategy in geographical terms. According to the ''Heartland theory', the Eurasian Area is 'the geographic pivot of history"' and ''Russia is the fortunate tenant"' that controls the "'pivot state', Mackinder (1904) has recorded the 'pivotal nature' of Eurasia with respect to 'vast amounts of its supplies in natural re- 
sources", its 'large population'” and the productive capabilities in the primary sector supported by 'railway networks', and a prevalent geomorphology that can provide Russia with the advantage "'to attack in multiple directions". Mackinder (Ibid.) considered Russia as the Eurasian power that could establish the "empire of the world' ' in a potential alliance either with Germany which could be a powerful and supportive center for the Russian 'ffleet-building'" or with China which could 'add an oceanic frontage to the resources of this great continent, an advantage as yet denied to the Russian tenant of the pivot region", 2 .

The Eurasian integration shows that Russia is inspired by Mackinder's theory and ascertains the option for an alliance with China rather than with Germany. Despite dynamics of the international system, it is clear that Russia cannot be the strategic mate of Germany that is the regional leader in European integration along with France joining both NATO's protective shield to counter Russia's expansion towards West. Tersely, if Russia had selected its interconnection with Germany and the West, it would inevitably reverted back to the past of the postSoviet transitive period leading probably to a Russia's EU membership. This perspective comes in full contrast with Russia's national aims, strategic tradition and geographic position in Eurasia, as it has already been observed in the framework of Realism's school of thought. Russia seeks its political preponderance and attains to upgrade its transcontinental status in consonance with its imperial past but China seems to be interested only for the status of the leading economic power of the world and not for the political one. Their strategic objectives and perspectives are not in conflict with each other.

Russia has chosen China as its new 'comrade' in a venture that corresponds to Mackinder's considerations. Although the 'Heartland Theory' became popular in the $20^{\text {th }}$ century, when main conditions of international politics such as balance of power, military technology and climate factors were extremely different to the current ones, it must be highlighted that several of its points remain open to consideration. More specifically, the borders of the current EAEU to a great extent are those of Mackinder's 'pivot state'. In economic terms, the EAEU urges an economic union across the Eurasian landmass where the aggregates may not yet be competitive to these of the US and the EU but, in respect of

\footnotetext{
${ }^{2}$ In its original consideration, Mackinder's (1904) argument was that:

', (...) even if Chinese, for instance, were organized by Japanese to overthrow the Russian Empire and conquer its territory, they might constitute the yellow peril to the world's freedom just because they would add an oceanic frontage to the resources of the great continent, an advantage as yet denied to the Russian tenant of the pivot region’’.
} 
resources and governance, EAEU perspectives are of great importance. The EAEU is a prospective political entity that draws resources from the Russian territory and disposes them to their allies as an integrated part of the TEAEU additionally to the Russian military power that protects the members of the EAEU in the framework of the CSTO. The latter corresponds to potential 'pivot state's"' hard power capabilities plus the Chinese supportive involvement in energy, trade and security being permanently institutionalized in the SCO integration and promoted by the OBOR. It can be argued that the Russo-Chinese alignment both in its bilateral and collective forms progressively establishes the fundamentals on a manifold complex of structures which are very familiar to Mackinder's 'pivot state'; that could probably re-order the global balance of power and give birth to new 'ordering superpowers' in the $21^{\text {st }}$ Century.

\section{Conclusion}

According to the theory of Grand Strategy, the Kremlin led Eurasian integration is the modern grand strategy of Russia and the EAU is a Moscow led prospective organization that could revive Russia's influence and power in Eurasia. The leading figure in this effort is Vladimir Putin, who adopted his strategy to bridge Russia's imperial past with Y. Primakov's post-Soviet integration and nowadays modalities and patterns of economic and political integration both at the intraregional level as well as at the global one. US preponderance in the post-Cold War international relations combined with its military supremacy that is supported by the EU - NATO coalition would probably jeopardize Russia's power across its former spheres of influence leading eventually to the total isolation of Moscow. Russia's grand strategy aims to unifying its allies under a new organization that will permit the Kremlin to assimilate the content of global governance and to synthesize the assets of 'soft power' with the hard power capabilities of the Russian Armed Forces. Nevertheless, according to modern distribution of state capabilities, Moscow needs a powerful ally to bid for the status of the preponderant political and military power in Europe and Asia and this ally is the People's Republic of China.

Russia and China are strategically intersected according to the analysis of the "'macroscopic types'” of Grand Strategy and are broadly interdependent establishing a special partnership both bilaterally and multilaterally into the framework of intraregional integration. Moscow and Beijing have advanced on agreements of great importance in the fields of energy, mutual trade, investments and security. This interdependence is upgraded by a collective security and trade structure in 
the SCO. The members of the SCO are mostly loyal allies of Moscow following it also in the CSTO and the EAEU. In essence, the SCO under the Russo-Chinese leadership meets the interests of Eurasian integration; the EAEU and the CSTO meet the interests of the SCO and the OBOR. In these organizations Russia and China join their forces and implement their strategies in tandem, although to promote separate but not contradictory final aims. Putin's Russia struggles for its geopolitical recovery and strives for the status of the preponderant power in Eurasia followed by China that takes steps to assert its geoeconomic control over Eurasia and to enhance consequently its position at the first place of the global market. Profoundly, the Eurasian grand strategy of Moscow is an endeavor that has international impact.

Key-theories of Classical and Structural Realism as well as Mackinder's Heartland theory decode the concept of Russia's Eurasian grand strategy into the context of Eurasian integration as well as its interaction with Russo-Chinese alliance at the level of the international system. According to the most influential Structural Realists such as Waltz and Mearsheimer the international system depends on 'ordering principles'" which are embedded by the ordering powers of the system.

These powers can be "'regional hegemons"' maximizing their power if they control another area next to which they preponderate. Russia adapts ''ordering principles"' derived from the US-NATO-EU coalition. In a similar way, Russia with China's help bids for a preponderant position in Europe and Asia and China respectively needs Russia's support to seek its economic preponderance. To this perspective, Mackinder's 'Heartland Theory' could probably be verified after more than a century. The Russian 'pivot Eurasian state' bids for the rise of a 'post-new world order' in consonance with dynamics of the international system.

\section{References}

Apostolakis, S. and Margaritou, K. (2018) 'Is Eurasian Economic Union Governance Effective? Implications for the Strategic Entrepreneurship and Innovation', International Journal of Comparative Management, Under Publication.

Arakelyan, L. (2014) 'The Soviet Union is Dead: Long Live the Eurasian Union', in Kanet, R. and Piet, R. (Eds.), Shifting Priorities in Russia's Foreign and Security Policy, Routledge, Abingdon, pp. 141-161.

ARKA (2015) 'Armenia to contribute \$1.8 million to EEU's 2016 budget.'

ARKA News Agency [online]


http://arka.am/en/news/economy/armenia_to_contribute_1_8_million_to_eeu_s_2 016_budget/ (Accessed 4 January 2016).

Aris, S. (2009) 'The Shanghai Cooperation Organization: 'Tackling the three evils'. A regional response to non-security challenges or an anti-Western bloc?’ Europe-Asia Studies, Vol. 61, No. 3, pp. 457-482.

Balassa, B. (1961) 'Towards a theory of economic integration', Kyklos International Review of Social Sciences, Vol. 14, No. 1, pp. 1-17.

Blank, S. (2015) 'Imperial ambitions: Russia's military buildup', World Affairs, Vol. 178, No. 1, pp. 67-75.

Boland, J. (2010) 'Learning from the Shanghai Cooperation Organization’s. Peace-Mission $2010 \quad$ Exercise.' Brookings [online] https://www.brookings.edu/opinions/learning-from-the-shanghai-cooperationorganizations-peace-mission-2010-exercise/ (Accessed 1 January 2014).

Bull, H. (2002) The Anarchical Society: A Study of Order in World Politics, $3^{\text {rd }}$ ed. Palgrave Macmillan, New York.

CIA, Factbook (2017). Russia. Energy [online]. CIA, Virginia. https://www.cia.gov/library/publications/the-world-factbook/geos/rs.html. (Accessed 5 January 2018).

China.org, Diplomatic Exchanges (2014). Xi's speech at 'Five Principles of Peaceful Coexistence' anniversary [online]. China.org, Beijing. http://www.china.org.cn/world/2014-07/07/content_32876905.htm. (Accessed 3 March 2015).

Collective Security Treaty Organization (2002). Chisinau, CSTO.

Eurasian Economic Commission, News and Events (2015a). The Treaty on the Eurasian Economic Union is effective [online]. EEC, Moscow. http://www.eurasiancommission.org/en/nae/news/Pages/01-01-2015-1.aspx. (Accessed 2 January 2015).

Eurasian Economic Commission, News and Events (2015b). Armenia is now in the Eurasian Economic Union [online]. EEC, Moscow. http://www.eurasiancommission.org/en/nae/news/Pages/02-01-2015-1.aspx. (Accessed 4 February 2015).

Eurasian Economic Commission, News and Events (2015c). Kyrgyzstan acceded to the Eurasian Economic Union [online]. EEC, Moscow. http://www.eurasiancommission.org/en/nae/news/Pages/12-08-2015-1.aspx. (Accessed 20 December 2015).

Eurasian Economic Commission, News and Events (2016). EEC published report on the four years of its operations [online]. EEC, Moscow. 
http://www.eurasiancommission.org/en/nae/news/Pages/24-02-2016-1.aspx. (Accessed 4 April 2016).

Eurasian Economic Commission, News and Events (2017). The Supreme Eurasian Economic Council (SEEC) conferred new powers in customs regulation to the Eurasian Economic Commission [online]. EEC, Moscow. http://www.eurasiancommission.org/en/nae/news/Pages/14-04-2017-1.aspx. (Accessed 28 December 2017).

Gazprom, News (2017). Russian gas supplies to China via Power of Siberia to start in December 2019 [online]. Gazprom, Moscow. http://www.gazprom.com/press/news/2017/july/article340477/. (Accessed 7 November 2017).

Gilpin, R. (2002) The Challenge of Global Capitalism. The World Economy in the 21st Century, Princeton University Press, New Jersey. Chichester.

Glencross, A. (2014) Politics of European Integration, Wiley Blackwell,

Hart, L. (1991) Strategy, $2^{\text {nd }}$ ed., Meridian Books, New York.

Hartwell, C. A. (2016) 'Improving competitiveness in the member states of the Eurasian Economic Union: a blueprint for the next decade', PostCommunist Economies, Vol. 28, No. 1, pp. 49-71.

Haas, E. B. (2008) Beyond the Nation State: Functionalism and International Organization, $2^{\text {nd }}$ ed. ECPR Press, Colchester.

Keating, M. and Loughlin J. (Eds.), (2004) The Political Economy of Regionalism, Routledge, Abingdon.

Kirkham, K. (2016) 'The formation of the Eurasian Economic Union: How successful is the Russian regional hegemony?', Journal of Eurasian Studies, Vol. 7, No. 2, pp. 111-128.

Krueger, A. O. (1997) 'Free trade agreements versus customs unions', Journal of Development Economics, Vol. 54, No. 1, pp. 169-187.

Lane, D. (2015) 'Eurasian Integration as a Response to Neoliberal Globalization', in Lane, D. and Samokhvalov, V. (Eds.), The Eurasian Project and Europe. Regional Discontinuities and Geopolitics, Palgrave Macmillan, New York, pp. 3-22.

Lang, P. and Ohr, R. (Eds.), (1995) International Economic Integration, Physica-Verlag, Heidelberg.

Lebow, R. N. (2013) 'Classical Realism', in Dunne, T. et al (eds.), International Relations Theories. Discipline and Diversity, $3^{\text {rd }}$ ed., Oxford University Press, Oxford, pp. 59-76. 
Lipsey, R. G. (1960) 'The Theory of Customs Union: A General Survey', The Economic Journal, Vol. 70, No. 279, pp. 496-513.

Lloyd, P. J. (1996) 'Regional Trading Arrangements and Regional Integration’, Asian Economic Journal, Vol. 10, No. 1, pp. 1-28.

Lomagin, N. (2014) 'Russia's CIS Policy and Economic and Political Transformations in Eurasia', in Kanet, R. and Piet, R. (Eds.), Shifting Priorities in Russia's Foreign and Security Policy, Routledge, Abingdon, pp. 115-139.

Luttwak, E. (1987) Strategy: The Logic of War and Peace, Harvard University Press, Massachusetts.

Mackinder, H. J. (1904) 'The Geographical Pivot of History', The Geographical Journal, Vol. 23, No. 4, pp. 421-437.

Margaritou, K. (2015) The Eurasian Union and the Grand Strategy of the Russian Federation (in Greek), I. Sideris, Athens.

Margaritou, K. (2017) The grand strategy of Eurasian Integration: The strategic interaction between the Eurasian Union and the Shanghai Cooperation Organisation. [online] Report in Greek language, Institute of International Economic Relations, Athens. http://idos.gr/ekthesi-tou-institoutou-diethnonikonomikon-scheseon-gia-tin-evrasiatiki-enosi/ (Accessed 28 December 2017).

Margaritou, K. (2018) Eurasian Union. Theory, Law, Policies and Strategy (in Greek, under publication), I. Sideris, Athens.

Mearsheimer, J. (2001) The Tragedy of Great Power Politics, Norton, New York.

Mearsheimer, J. (2013) 'Structural Realism', in Dunne, T. et al (eds.), International Relations Theories. Discipline and Diversity, $3^{\text {rd }}$ ed., Oxford University Press, Oxford, pp. 77-93.

Meshceryakov, K.Y. (2014a) 'Russia’s Central Asian Alliances: The Real Deal?’, World Applied Sciences Journal, Vol. 30, No. 12, pp. 1781-1783.

Meshceryakov, K. Y. (2014b) 'Central Asian Integration and Russian Foreign Policy’, Middle - East Journal of Scientific Research, Vol. 21, No. 1, 66 -70. Oxford.

Mitrany, D. (1944) A Working Peace System, Oxford University Press,

Morgenthau, H. (1947) Scientific Man VS Power Politics, Latimer House, London.

Morgenthau, H. (1978) Politics Among Nations. The Struggle for Power and Peace, Alfred Knorf, New York.

Nye, J. S. (1968) International Regionalism, Little Brown, Boston.

Nye, J. S. (2004) Soft Power. The means to Success in World Politics, Public Affairs, New York. 
Nye, J. S. (2008) 'Toward a Liberal Realist Policy: A memo for the next President.' Harvard Magazine, March-April 2008 [online] https://harvardmagazine.com/2008/03/toward-a-liberal-realist.html (Accessed 12 December 2012).

Panda, A. (2014) 'Reflecting on China's Five Principles, 60 Years Later.' The Diplomat [online] https://thediplomat.com/2014/06/reflecting-on-chinas-fiveprinciples-60-years-later/ (Accessed 3 March 2015). Athens.

Papasotiriou, H. (2011) Byzantine Grand Strategy (in Greek), Poiotita,

Papasotiriou, H. (2013) China: From the Celestial Empire to the Emerging Power of the $21^{\text {st }}$ Century (in Greek), Poiotita, Athens.

Persson, G. (2013) 'Security Policy and Military Strategic Thinking', in Hedenskog, J. and Pallin, C. V. (Eds.) Russian Military Capability in a Ten - Year Perspective, FOI, Stockholm, pp. $71-88$.

(The) President of Russia, Events (2016a). Interview to the Xinhua News Agency of China [online]. The President of Russia, Moscow. http://en.kremlin.ru/events/president/news/52204. (Accessed 24 June 2016).

(The) President of Russia, Events, Events (2016b). Meeting with President of China Xi Jinping [online]. The President of Russia, Moscow. http://en.kremlin.ru/events/president/news/52240. (Accessed 24 June 2016).

Putin, V. (2011) 'A new integration project for Eurasia: The future in the making.’ Izvestia [online] https://www.rusemb.org.uk/press/246 (Accessed 12 May 2012).

Qoraboyev, I. (2010) 'From Central Asian Regional Integration to Eurasian Integration Space? The Changing Dynamics of Post-Soviet Regionalism', in Vikonurov, E. (Eds.), EDB Eurasian Integration Yearbook, Eurasian Development Bank, Almaty, pp. 206-232.

Riezman, R. (Eds.), (2013) International Trade Agreements and Political Economy, World Scientific Publishing, Singapore.

Roberts, S. P. and Moshes, A. (2016) 'The Eurasian Economic Union: a case of reproductive integration?', Post-Soviet Affairs, Vol. 32, No. 6, pp. 542-565.

Rosamond, B. (2000) Theories of European Integration. St. Martin's Press, New York.

Russia at a glance. [online] http://www.investinrussia.biz/russia-glance (Accessed 13 January 2018).

Reuters (2016) 'Russia's Putin says no obstacles for Iran to join SCO.' Reuters World News [online] https://www.reuters.com/article/us-uzbekistan-sco- 
russia-iran/russias-putin-says-no-obstacles-for-iran-to-join-scoidUSKCN0ZA0YQ (Accessed 8 August 2016).

RT (2015) 'Israel wants free trade zone with Eurasian Union.' Russia Today News [online] https://www.rt.com/business/319947-Israel-Russia-EEU-trade/ (Accessed 28 October 2015).

RT (2016a) 'Russia, China approve business initiatives worth \$50bn during Putin visit.' Russia Today News [online] https://www.rt.com/business/348391putin-china-visit-rosneft/ (Accessed 25 June 2016).

RT (2016b) “'Our views are either similar or coincide': Putin on comprehensive strategic China-Russia alliance.' Russia Today News [online] https://www.rt.com/news/347879-putin-russia-china-alliance/ (Accessed 24 June 2016).

RT (2018) 'Russia-China trade volume exceeds expectations, hitting \$84bn.’ Russia Today News [online] https://www.rt.com/business/415692-russiachina-trade-turnover/ (Accessed 18 January 2018).

Security Council of the Russian Federation (2000). National Security Concept of the Russian Federation [online]. Ministry of Foreign Affairs of the Russian Federation, Moscow. http://www.mid.ru/en/foreign_policy/official_documents//asset_publisher/CptICk B6BZ29/content/id/589768. (Accessed 14 January 2014).

Security Council of the Russian Federation (2008). The Foreign Policy Concept of the Russian Federation [online]. President of Russia, Moscow. http://en.kremlin.ru/supplement/4116 (Accessed 14 January 2014).

Security Council of the Russian Federation (2009). National Security Strategy of the Russian Federation to 2020 [online]. Rustrans (unofficial translation), place unknown. http://rustrans.wikidot.com/russia-s-national-securitystrategy-to-2020 (Accessed 14 January 2014).

Security Council of the Russian Federation (2010). The Military Doctrine of the Russian Federation [online]. Carnegie (unofficial translation), place unknown. http://carnegieendowment.org/files/2010russia_military_doctrine.pdf (Accessed 14 January 2014).

Security Council of the Russian Federation (2013). Concept of the Foreign Policy of the Russian Federation [online]. Ministry of Foreign Affairs of the Russian Federation, Moscow. http://www.mid.ru/en/foreign_policy/official_documents//asset_publisher/CptICk B6BZ29/content/id/122186 (Accessed 14 January 2014). 
Security Council of the Russian Federation (2014). The Military Doctrine of the Russian Federation [online]. Embassy of the Russian Federation to the UK, London. http://rusemb.org.uk/press/2029 (Accessed 15 October 2015).

Security Council of the Russian Federation (2015). The Russian Federation's National Security Strategy [online]. Spanish Ministry of Defense, Spanish Institute for Strategic Studies (unofficial translation), Madrid. http://www.ieee.es/Galerias/fichero/OtrasPublicaciones/Internacional/2016/Russia n-National-Security-Strategy-31Dec2015.pdf (Accessed 6 June 2016).

Security Council of the Russian Federation (2016). The Foreign Policy Concept of the Russian Federation [online]. Ministry of Foreign Affairs of the Russian Federation, Moscow. http://www.mid.ru/en/foreign_policy/official_documents//asset_publisher/CptICkB6BZ29/content/id/2542248 (Accessed 15 January 2017).

Shearman, P. (2015) 'Putin and Russian Policy Toward the West', in Kanet, R. and Sussex, M. (Eds.), Power, Politics and Confrontation in Eurasia, Palgrave Macmillan, New York, pp. 63-88.

State Council of the People's Republic of China, Information Office, (2011a). White Paper on China's Peaceful Development. Information Office of the State Council of the People's Republic of China [online]. State Council of the PRC, Beijing. http://www.china.org.cn/government/whitepaper/201109/06/content_23362712.htm. (Accessed 3 March 2015).

State Council of the People's Republic of China, Information Office, (2011b). White Paper on National Defense Policy. Information Office of the State Council of the People's Republic of China [online]. State Council of the PRC, Beijing. $\quad$ http://www.china.org.cn/government/whitepaper/201103/31/content_22263420.htm. (Accessed 3 March 2015).

Tiezzi, S. (2014) 'China hosts SCO’s largest-ever military drills.' The Diplomat [online] http://thediplomat.com/2014/08/china-hosts-scos-largest-evermilitary-drills/ (Accessed 18 October 2014).

Tolipov, F. (2005) 'CACO merges with EEC: The third strike on Central Asia's independence', The CACI Analyst [online] 19 October. http://www.cacianalyst.org/publications/analytical-articles/item/10376-analyticalarticles-caci-analyst-2005-10-19-art-10376.html (Accessed 11 January 2012).

Treaty on the Eurasian Economic Union (2014). Astana, EAEU.

Vikonurov, E. (2013) 'Pragmatic Eurasianism', Russia in Global Politics, Vol. 11, No. 2, pp. 87-96.

Vinokurov, E. (2017) 'Eurasian Economic Union: Current state and preliminary results', Russian Journal of Economics, Vol. 3, No. 1, pp. 54-70. 
Waltz, K. (1979) Theory of International Politics, Addison-Wesley, Massachusetts.

Waltz, K. (2000) 'Structural Realism after the Cold War', International Security, Vol. 25, No. 1, pp. 5-41. 